\title{
Pánrezisztens kórokozók által okozott többlethalálozás: mi áll valójában a szakirodalomban?
}

\author{
Excess mortality due to pandrug resistant bacteria: \\ a survey of the literature
}

Szerző: $\quad$ Gajdács Márió $\square$

Szegedi Tudományegyetem Általános Orvostudományi Kar Klinikai Mikrobiológiai Diagnosztikai Intézet

Beküldve: 2019. 01. 02.

doi: $\quad$ 10.24365/ef.v60i2.397

\begin{abstract}
Összefoglaló: Az antibiotikumok felfedezése és klinikumban alkalmazása az egészségügy történetének egyik legnagyobb sikere, azonban az antibiotikum-rezisztens kórokozók globális terjedésével az eddigi eredmények veszélybe kerültek. A bakteriális rezisztencia problémájáról számos jelentést és szakmai ajánlást tettek közzé, azonban fontos megjegyezni, hogy az összes fent említett jelentésben közölt mortalitási adatok matematikai modelleken alapuló, becsült értékek.

A releváns, angol és magyar nyelvű közlemények kiválasztását irodalomkutatás előzte meg a PubMed adatbázisban. A beválogatott cikkek közé a megfelelő kulcsszavak felhasználásával azok a 2018. december 10. előtt megjelent publikációk kerültek, amelyek pánrezisztens (PDR) bakteriális infekciók által közvetlenül okozott halálesetekről számoltak be a humán gyógyászatban.

Az irodalomkutatás során a PubMed adatbázisából 2386 közlemény felelt meg a keresési kritériumoknak. Ebből mindössze négy olyan közleményt sikerült azonosítani, amely összesen 14 PDR-asszociált halálesetről számol be. Öt esetben mucoviscidosisban (cisztikus fibrózis) szenvedő betegeket vizsgáltak, $s$ a legtöbb halálos kimenetelú eset PDR Klebsiella pneumoniae-hez volt köthető.

Habár a felhasznált kutatási módszernek vannak korlátai, az eredmények azt sugallják, hogy a tudományos folyóiratokban publikált, pánrezisztens kórokozók miatt bekövetkezett halálesetek száma nincs összhangban a nemzetközi jelentésekben közölt becsült többlethalálozás (23 000-25 000/év) mértékével. Az antibiotikum-rezisztenciához kapcsolódó problémakör rendkivül összetett, amely az új antibiotikumok fejlesztésén túl az antibiotikumok legmegfelelőbb felhasználására és az optimális terápia kiválasztására irányuló törekvésekben, illetve a szigorú infekciókontroll- tevékenységekben nyilvánul meg.

Kulcsszavak: antibiotikum; pánrezisztencia; PDR; irodalomkutatás
\end{abstract}

Summary: The discovery and use of antibiotics in the clinical practice can be considered as one of the greatest successes in the history of medicine, but with the global spread of antibiotic resistant pathogens, the results of this success story are being compromised. Many reports and professional recommendations have been published on the significance of bacterial resistance, but it is important to note that all mortality data reported in these reports are based on estimated values based on mathematical models.

A literature search was conducted using PubMed database to look for relevant publication. During the course of this study, publications reporting on deaths directly attributable to 
pandrug-resistant (PDR) bacterial infections and published before 10th December, 2018 were included, using appropriate keywords. English and Hungarian publications were analyzed.

In the course of literature search, 2386 publications matched the search criteria from PubMed. A total of four communications have been identified that report a total of 14 PDR-associated deaths. In five cases, patients had cystic fibrosis and most fatal cases were associated with PDR Klebsiella pneumoniae.

Although there are limitations to this study, the results suggest that the number of deaths caused by pandrug-resistant pathogens is inconsistent with the estimated extra-mortality (23000-25000 per year) published in international reports. The problem of antibiotic resistance is extremely complex, in addition to the development of new antibiotics, the solutions include the prudent use of these drugs and strict infection control measures.

Keywords: antibiotic; pandrug resistance; PDR; literature search

\section{BEVEZETÉS}

$\mathrm{Az}$ antibiotikumok felfedezését és klinikumban alkalmazását az egészségügy történetének egyik legnagyobb sikerének tekinthetjük. Ezen „csodaszereknek" köszönhetően lehetővé vált mind a kisebb, mind pedig az életveszélyes infekciók kezelése. Emellett biztosították a komplex sebészeti beavatkozások, a szervtranszplantációk és a daganatellenes terápia robbanásszerű fejlődését, hiszen magasabb dózisban tudták alkalmazni a klasszikus (citotoxikus) kemoterápiás szereket, mellyel sikeresen megnövelték a betegek túlélését. ${ }^{1}$ Az antibiotikum-rezisztens kórokozók globális terjedésével az eddigi eredmények veszélybe kerültek, s ez a folyamat az egészségügyet az ún. „pre-antibiotikum"- érába vezetheti vissza. ${ }^{2} \mathrm{Az}$ antibiotikumrezisztencia jelensége az egészségügyben összetett probléma, melynek számos mozgatórugója van. ${ }^{3,4,5}$ Az antibiotikumok nem megfelelő használatán túl (a humán- és állatgyógyászatban egyaránt) a gyógyszercégek csökkent érdeklődése is komoly nehézséget jelent. A rezisztens kórokozók egyre gyakoribb megjelenése ellenére az újonnan törzskönyvezett antibiotikumok száma 90\%-kal csökkent az elmúlt 30 évben. $^{2}$

A bakteriális rezisztencia jelentőségéről számos jelentést és szakmai ajánlást tettek közzé. Az Európai Betegségmegelőzési és Járványvédelmi Központ (ECDC) 2009 végén kiadott jelentése szerint az Európai Unió tagországai évente legalább 400000 multirezisztens (MDR) kórokozó által okozott fertőzést jelentenek be, amely adat mögött évente több mint 25 millió kórházban töltött nap és kb. 25000 fő többletmortalitás áll. ${ }^{6} \mathrm{Az}$ Amerikai Járványvédelmi Központ (CDC) 2017-ben közzétett becslése hasonló eredményre jutott, miszerint az Egyesült Államokban közel 2 millió fertőzést jelentenek, ez az adat évente kb. 23000 fő többlethalálozását mutatja. ${ }^{7} \mathrm{Az}$ Egészségügyi Világszervezet (WHO) 2014-ben kiadott jelentésében öt meta-analízis eredményeinek értékelése után (melyben összesen 221 vizsgálat adatait elemezték) arra a következtetésre jutottak, hogy több, antibiotikummal szemben rezisztens kórokozó kimutatása összefüggésbe hozható a rosszabb klinikai kimenetellel. ${ }^{8} 2016$ szeptember 26-án az Egyesült Nemzetek Szervezetén (UN) belül a világ politikai vezetői is tárgyaltak a rezisztens kórokozók okozta veszélyről. ${ }^{9}$ Ezen az ülésen egy olyan, Egyesült Királyságból származó vizsgálatra hivatkoztak, mely 2050-re az MDR kórokozók miatti évi 10 millió halálesetet és 100 billió dollár kapcsolódó pénzügyi terhet becsült meg. ${ }^{10}$ Egy viszonylag friss közleményben pedig az Európai Unió és az Európai Gazdasági Közösség területére vonatkozóan végeztek becsléseket, melynek eredményeképpen 671689 multirezisztens kórokozó általi fertőzést, 33110 fő többlethalálozást és 874541 rokkantsággal (korlátozottsággal) korrigált, elveszített potenciális életévet (DALY) becsültek a 2015-ös évre vonatkozóan. ${ }^{11}$ Azonban fontos megjegyezni, hogy az összes fent említett, nemzetközi jelentésben közölt mortalitási adatok matematikai modelleken alapuló, becsült értékek, s nem végeztek összehasonlításokat a tudományos szakirodalomban jegyzett halálesetek és a multirezisztens baktérium törzsek okozta infekciók közötti összefüggésekkel kapcsolatban. ${ }^{12}$ Magyarországon a Nemzeti Nozokomiális Surveillance Rendszerben találhatunk az egészségügyi ellátással összefüggő infekciókkal kapcsolatos aggregált adatokat. 
Ezen felül problémát jelent az is, hogy a legtöbb vizsgálatban nem egységes az MDR kórokozó fogalma sem. [1. táblázat] A bakteriális rezisztencia súlyossága szempontjából az ECDC és a CDC által összehívott szakértői csoport konszenzusa alapján kialakított ajánlás alapján három kategóriát különböztethetünk meg: 1) multirezisztens (MDR) az a baktérium törzs, mely rezisztenciát mutat legalább egy, három vagy több antibiotikumosztályba tartozó antibiotikumra, 2) kiterjedt rezisztenciával rendelkezik (extensively drug-resistant, XDR) az a törzs, amely kettő vagy ennél kevesebb antibiotikum- csoporttal szemben mutat érzékenységet, és 3) pándrogrezisztens (pandrug-resistant, PDR) kórokozók, amelyek nem mutatnak érzékenységet egyik antibiotikummal szemben sem. ${ }^{13}$ Fontos kiemelni, hogy az egyes kórokozó baktériumokra hatékony antibiotikumok száma és az esetleges természetes rezisztenciamechanizmusok jelenléte is befolyásolhatja ezt a besorolást: ahhoz, hogy egy Klebsiella pneumoniae törzs XDR legyen, már csak két antibiotikum-csoporttal szemben mutat érzékenységet (pl. egy karbapenemáz-termelő, de colistinre és tigeciklinre érzékeny törzs esetén). Ezzel szemben egy Stenotrophomonas maltophilia törzs esetén (mivel kevés a klinikailag bizonyítottan hatékony antibiotikum) már a szulfametoxazoltrimetoprim rezisztencia esetén XDR törzsről beszélünk.

A kutatás célja a jelenleg elérhető szakirodalmi adatok feltérképezése a multirezisztens, a kiterjedt rezisztenciával rendelkező és a pánrezisztens baktériumok által okozott fertőzéseknek közvetlenül betudható halálozások gyakoriságát illetően.

1. táblázat: Multirezisztens kórokozóknak tekintett baktériumok a különböző hazai és nemzetközi ajánlásokban

\begin{tabular}{|c|c|c|c|}
\hline ECDC jelentés 6 & WHO jelentés ${ }^{8}$ & $\begin{array}{l}\text { CDC jelentés (sürgős és sú- } \\
\text { lyos fenyegetések) }{ }^{7}\end{array}$ & $\begin{array}{c}\text { Nemzeti Nozokomiális Surveillance } \\
\text { Rendszerben (NNSR) figyelt kór- } \\
\text { okozók }^{14}\end{array}$ \\
\hline $\begin{array}{l}\text { Methicillin-rezisztens } \\
\text { Staphylococcus aureus } \\
\text { (MRSA) }\end{array}$ & $\begin{array}{l}\text { Methicillin-rezisztens } \\
\text { Staphylococcus aureus } \\
\text { (MRSA) }\end{array}$ & $\begin{array}{l}\text { Karbapenem-rezisztens } \\
\text { Enterobacteriaceae (CRE) }\end{array}$ & $\begin{array}{l}\text { Methicillin/oxacillin-rezisztens } \\
\text { Staphylococcus aureus (MRSA) }\end{array}$ \\
\hline $\begin{array}{c}\text { Vankomycinre mérsékelten } \\
\text { érzékeny vagy rezisztens } \\
\text { Staphylococcus aureus (VISA, } \\
\text { VRSA) }\end{array}$ & $\begin{array}{l}\text { 3. generációs cefalospori- } \\
\text { nokra és fluorokinolokra } \\
\text { rezisztens Escherichia coli }\end{array}$ & $\begin{array}{l}\text { Multidrog rezisztens Aci- } \\
\text { netobacter baumannii }\end{array}$ & $\begin{array}{c}\text { Vankomycinre mérsékelten érzé- } \\
\text { keny Staphylococcus aureus } \\
\text { (VISA) }\end{array}$ \\
\hline $\begin{array}{l}\text { Penicillin-rezisztens Strepto- } \\
\text { coccus pneumoniae }\end{array}$ & $\begin{array}{l}\text { Karbapenem-rezisztens } \\
\text { Klebsiella pneumoniae }\end{array}$ & Rezisztens Campylobacter & $\begin{array}{c}\text { Vankomycin-rezisztens Enterococ- } \\
\text { cus (VRE) }\end{array}$ \\
\hline $\begin{array}{l}\text { 3. generációs cefalospori- } \\
\text { nokra rezisztens Escherichia } \\
\text { coli és Klebsiella pneumoniae }\end{array}$ & & $\begin{array}{l}\text { Flukonazol-rezisztens } \\
\text { Candida }\end{array}$ & $\begin{array}{c}\text { Multirezisztens Pseudomonas } \\
\text { aeruginosa (MPAE) }\end{array}$ \\
\hline $\begin{array}{c}\text { Karbapenem-rezisztens } \\
\text { Escherichia coli és Klebsiella } \\
\text { pneumoniae }\end{array}$ & & $\begin{array}{l}\text { Rezisztens Neisseria go- } \\
\text { norrhoeae }\end{array}$ & $\begin{array}{l}\text { Sumetrolim-rezisztens Stenot- } \\
\text { rophomonas maltophilia (MSTM) }\end{array}$ \\
\hline \multirow[t]{7}{*}{$\begin{array}{l}\text { Karbapenem-rezisztens Pseu- } \\
\text { domonas aeruginosa }\end{array}$} & & $\begin{array}{c}\text { Kiterjedt-spektrumú béta- } \\
\text { laktamáz-termelő (ESBL) } \\
\text { Enterobacteriaceae } \\
\end{array}$ & $\begin{array}{l}\text { Imipenem/meropenem-rezisztens } \\
\text { Acinetobacter baumannii (MACI) }\end{array}$ \\
\hline & & $\begin{array}{l}\text { Vankomycin-rezisztens } \\
\text { Enterococcus (VRE) }\end{array}$ & $\begin{array}{c}\text { ESBL-termelő/imipenem/merope- } \\
\text { nem-rezisztens Escherichia coli } \\
\text { (MECO) }\end{array}$ \\
\hline & & $\begin{array}{l}\text { Multidrog rezisztens Pseu- } \\
\text { domonas aeruginosa }\end{array}$ & $\begin{array}{c}\text { ESBL-termelő/imipenem/merope- } \\
\text { nem-rezisztens Klebsiella spp. } \\
\text { (MKLE) }\end{array}$ \\
\hline & & Rezisztens Shigella & $\begin{array}{l}\text { Imipenem/meropenem-rezisztens } \\
\text { Enterobacter spp. (MENB) }\end{array}$ \\
\hline & & $\begin{array}{c}\text { Rezisztens Salmonella } \\
\text { Typhi }\end{array}$ & \multirow{3}{*}{$\begin{array}{l}\text { Imipenem/meropenem nem érzé- } \\
\text { keny és/vagy karbapenemáz ter- } \\
\text { melő egyéb Enterobacteriaceae } \\
\text { (CRE) }\end{array}$} \\
\hline & & $\begin{array}{c}\text { Methicillin-rezisztens } \\
\text { Staphylococcus aureus } \\
\text { (MRSA) }\end{array}$ & \\
\hline & & $\begin{array}{l}\text { Penicillin-rezisztens Strep- } \\
\text { tococcus pneumoniae }\end{array}$ & \\
\hline
\end{tabular}




\section{MÓDSZERTAN}

A releváns közlemények kiválasztásához irodalomkutatást végeztem a PubMed adatbázisban az Abat és mtsai. által kidolgozott protokoll alapján. ${ }^{15}$ A kutatás során azokat a 2018. december 10. előtt megjelent publikációkat válogattam be, amelyek PDR- bakteriális infekciók által közvetlenül okozott halálesetekről számoltak be a humán gyógyászatban, illetve ahol a PDR- kórokozó definiálása során igazodtak az ESCMID által kiadott irányelvekhez. A szakirodalom elemzése során angol és magyar nyelvű közleményeket egyaránt elemeztem. A PubMed keresőmotorjában az alábbi kulcsszavakat használtam: "therapeutic dead end", "therapeutic impasse", "treatment pitfalls", "treatment failure", „pan drug resistant", „pan-drug-resistant”, „pan-drug resistant”,"multidrug-resistant", „multi-drug resistant”, „multi drug resistant", "extremely-drugresistant, "extremelydrug resistant", "extremely drug resistant", "extensively drug resistant", "extensively drugresistant”, „panresistant”, „pan-resistant”, „panresistance”, minden esetben párosítva a "bacteria” kulcsszóval.

\section{EREDMÉNYEK}

Az irodalomkutatás során a PubMed adatbázisából 2386 közlemény felelt meg a keresési kritériumoknak, amelyek közül a közleménycímek és összefoglalók áttanulmányozása után 583 került a beválogatottak közé teljes elemzés céljából. Ezek részletes áttekintése során összesen négy olyan közleményt sikerült azonosítani, amely PDR- baktériumtörzsek által közvetlenül okozott haláleseteket ír le. ${ }^{15,16}$ A négy közlemény összesen 14 PDR-asszociált halálesetről számol be. A PDR-fertőzésnek betudható halálozást az alábbi kritériumok alapján határozták meg: a. a beteg mintájából kitenyészett a kórokozó, amit a helyi antibiotikum-érzékenységi vizsgálatok alapján PDR-nek klasszifikáltak, b. a PDR-baktérium a laborparaméterek és a klinikai kép alapján patogén (nem kolonizáció vagy kontamináció), c. 30 napos összmortalitás. Két közleményben hasonlították össze a multirezisztens és nem rezisztens kórokozókkal fertőzött betegek halálozási arányát, és szignifikáns különbséget találtak a multirezisztens kórokozók által okozott fertőzések „javára”. ${ }^{17,18}$ Öt esetben mucoviscidosisban (cisztikus fibrózis) szenvedő betegeket vizsgáltak, s a legtöbb halálos kimenetelű eset PDR Klebsiella pneumoniae-hez volt köthető (8 haláleset). A közleményekben a PDR- infekciók mortalitási rátája 6,7-33,33\% között változott.[2. táblázat]

2. táblázat: Az irodalomkutatás során talált releváns közlemények

\begin{tabular}{|c|c|c|c|c|c|c|}
\hline Ország & PDR baktérium törzs & $\begin{array}{l}\text { PDR-asszoci- } \\
\text { ált halálozá- } \\
\text { sok száma }\end{array}$ & $\begin{array}{l}\text { Halálozási } \\
\text { arány }\end{array}$ & $\begin{array}{l}\text { Alapbeteg- } \\
\text { ség }\end{array}$ & Fertőzés típusa & Minta típusa \\
\hline \multirow{2}{*}{ Ausztrália ${ }^{16}$} & $\begin{array}{c}\text { Pseudomonas aerugi- } \\
\text { nosa }\end{array}$ & \multirow{2}{*}{2} & \multirow{2}{*}{$6,70 \%$} & \multirow{2}{*}{$\begin{array}{l}\text { Mucovisci- } \\
\text { dosis }\end{array}$} & \multirow{2}{*}{ Bronchopneumonia } & \multirow{2}{*}{ Köpet } \\
\hline & $\begin{array}{c}\text { Stenotrophomonas } \\
\text { maltophilia }\end{array}$ & & & & & \\
\hline \multirow{2}{*}{$\begin{array}{l}\text { Görög- } \\
\text { ország18 }^{18}\end{array}$} & $\begin{array}{c}\text { Acinetobacter bau- } \\
\text { mannii }\end{array}$ & \multirow[t]{2}{*}{8} & \multirow[t]{2}{*}{$33,30 \%$} & \multirow[t]{2}{*}{ Számos } & \multirow{2}{*}{$\begin{array}{l}\text { Bronchopneumonia, } \\
\text { véráramfertőzés }\end{array}$} & \multirow[t]{2}{*}{ Számos } \\
\hline & Klebsiella pneumoniae & & & & & \\
\hline $\begin{array}{c}\text { Egyesült } \\
\text { Államok }^{19}\end{array}$ & Klebsiella pneumoniae & 1 & * & Májtályog & Véráramfertőzés & $\begin{array}{l}\text { Hemokul- } \\
\text { túra }\end{array}$ \\
\hline $\begin{array}{l}\text { Egyesült } \\
\text { Államok és } \\
\text { Kanada }^{17}\end{array}$ & $\begin{array}{l}\text { Pseudomonas aerugi- } \\
\text { nosa }\end{array}$ & 3 & $6,70 \%$ & $\begin{array}{l}\text { Mucovisci- } \\
\text { dosis }\end{array}$ & Bronchopneumonia & Köpet \\
\hline
\end{tabular}




\section{ÖSSZEGZÉS}

Az irodalomkutatás során négy olyan közleményt sikerült azonosítani, amelyek a feldolgozott 14 halálesetet közvetlenül a PDR- kórokozók általi infekciónak tulajdonították. A négy közleményből három esetén a baktériumok PDR- státuszát úgy határozták meg, hogy nem vizsgálták az érzékenységüket minden releváns antibiotikum-csoporttal szemben (3-5 antibiotikum-csoportot vizsgáltak). Ennélfogva az is előfordulhat, hogy további antibiotikumokkal szembeni érzékenységük vizsgálatával a fenti közleményekben említett törzsek "csak” XDR státuszúak lennének. Az ECDC 2009-es jelentéséből (amely 25000 kapcsolódó halálesetet becsül évente az EU 506 millió lakosságszámára vonatkoztatva) az következne, hogy Magyarországon (2018-as lakossági adat: 9778371 fő) kb. 480 fő hal meg évente a kapcsolódó MDR/XDR/PDR- infekciók következtében. ${ }^{6,20} \mathrm{Az}$ irodalomkutatás eredményeképpen azonban csupán négy olyan közleményt sikerült találni globálisan, ahol közvetlenül a PDRinfekcióhoz kapcsolódó halálesetről számoltak be (habár arra nincs garancia, hogy ezek a baktériumok valójában megfelelnek a PDR definíciójának). A fent említett jelentések közük egyik sem használt robusztus, standardizált módszert a MDR-PDR-baktériumok általi többlethalálozás mértékének meghatározására: a MDR-baktériumok okozta fertőzések számának becsléséhez az egyes baktériumfajokra és az invazív infekciókra vonatkoztatott arányszámokat használtak, amelyeket meta-analízisek alapján határoztak meg. Végezetül az MDRbaktériumok okozta halálozási arányt az egyes baktériumfajok és az egyes fertőzéstípusok által okozott mortalitás arányának becslésével határozták meg. Továbbá nem egységes definíciót használnak az MDR patogénekre. Végezetül, ezek a jelentések nem tértek ki arra sem, hogy a becsült többlethalálozás az MDR- infekció közvetlen következménye, vagy a komplex egészségügyi helyzetekben csupán súlyosbító tényezőként szerepel. ${ }^{21}$ Ez különösen jelentős az idős, immunhiányos állapotban lévő, komplex alapbetegségekben szenvedő betegcsoportok esetén, ahol a beteg súlyos állapota nagyobb valószínűséggel fog halálozáshoz vezetni. A nem megfelelő empirikus terápiában részesülő betegek szintén torzíthatják az elemzéseket, hiszen ilyen esetekben a mortalitási ráta a rezisztenciaviszonyoktól függetlenül szinte kivétel nélkül magasabb. ${ }^{21}$

\section{KÖVETKEZTETÉSEK}

Habár a felhasznált kutatási módszernek (a szakirodalom áttekintése) vannak korlátai, az eredmények azt sugallják, hogy a tudományos folyóiratokban publikált MDR/XDR/PDR- kórokozók által okozott halálesetek száma nincs összhangban a nemzetközi jelentésekben közölt, becsült többlethalálozás mértékével. További korlátnak tekinthető, hogy a multirezisztens kórokozókkal kapcsolatos szakirodalom rendkívül gazdag, mind az alapkutatás, mind a klinikai esetek tekintetében, így más kulcsszavak felhasználásával (pl. MRSA, VRE, CRE) valószínúleg további vagy más jellegű közlemények is felmerültek volna az irodalomkutatás során. Az antibiotikum-rezisztenciához kapcsolódó problémakör a fentieknél természetesen sokkal összetettebb, s még akkor is érdemes kritikát gyakorolni, ha ezeket a tanulmányokat több ezer közlemény szerzője idézi saját kutatási eredményeik alátámasztására. Az antibiotikum- rezisztencia problémájának megoldása az új antibiotikumok fejlesztésén túl az antibiotikumok legmegfelelőbb felhasználására (antibiotic stewardship) és az optimális terápia kiválasztására irányuló törekvésekben (klinikai mikrobiológiai laboratóriumok szerepe), illetve a szigorú infekciókontroll- tevékenységekben nyilvánul meg, mind az alapellátás, mind a fekvőbetegszakellátás területén.

\section{KÖSZÖNETNYILVÁNÍTÁS}

A közlemény létrejöttét az ESCMID Mentorprogram és az NTP-NFTÖ-18-C-0225 „Nemzet Fiatal Tehetségeiért Ösztöndíj" támogatta. 
HIVATKOZÁSOK

\footnotetext{
${ }^{1}$ Andersson DI, Hughes D. Antibiotic resistance and its cost:is it possible to reverse resistance? Nat Rev Microbiol 2010; 8: 260-71.

2 Bush K, Courvalin P, Dantas G et al. Tackling antibiotic resistance. Nat Rev Microbiol 2011; 9: 894-6.

${ }^{3}$ Spengler G, Kincses A, Gajdács M et al. New Roads Leading to Old Destinations: Efflux Pumps as Targets to Reverse Multidrug Resistance in Bacteria. Molecules 2017; 22(3):468. https://doi.org/10.3390/molecules22030468

${ }^{4}$ Gajdács M, Paulik E, Szabó A. Közforgalomban dolgozó gyógyszerészek antibiotikum felhasználással és rezisztenciával kapcsolatos véleménye. Acta Pharm Hung 2018; 88(43):249-52.

${ }^{5}$ Gajdács M, Paulik E, Szabó A. Közforgalomban dolgozó gyógyszerészek attitűdvizsgálata a fertőző betegségekkel kapcsolatos szerepkörük kiszélesítésére vonatkozóan Magyarország délkeleti részén. Gyógyszerészet 2019; 63(1): 26-30.

${ }^{6}$ ECDC/EMEA Joint Technical Report (2009) The bacterial challenge: time to react. 2009. http://ecdc.europa.eu/en/publications/Publications/0909 TER The Bacterial Challenge Time to React.pdf (Elérve: 2018. 12. 30.)

${ }^{7}$ CDC Antibiotic/Antimicrobial Resistance (AR/AMR). https://www.cdc.gov/drugresistance/biggest threats.html (Elérve: 2018. 12. 30.)

${ }^{8}$ World Health Organization (2014) Antimicrobial resistance: global report on surveillance.
} http://apps.who.int/iris/bitstream/10665/112642/1/9789241564748 eng.pdf. (Elérve: 2018. 12. 30.)

${ }_{9}$ Political Declaration of the High-Level Meeting of the General Assembly on Antimicrobial Resistance: draft resolution. United Nations Digital Libary https://digitallibrary.un.org/record/842813?!n=en (Elérve: 2018. 12. 30.)

${ }^{10}$ O'Neill J (2014) Antimicrobial resistance: tackling a crisis for the health and wealth of nations. https://amr-review.org/sites/default/files/AMRReviewPaper-Tacklingacrisisforthehealthandwealthofnations 1.pdf

(Elérve: 2018. 12. 30.)

${ }^{11}$ Cassini A, Högberg D-L, Plachouras D et al. Attributable deaths and disability-adjusted life-years caused by infections with antibiotic-resistant bacteria in the EU and the European Economic Area in 2015: a population-level modelling analysis. Lancet Infect Dis 2019; 19(1):55-56.

${ }^{12}$ Abat C, Rolain J-M, Dubourg G et al. Evaluating the clinical burden and mortality attributable to antibiotic resistance: the disparity of empirical data and simple model estimations. Clin Infect Dis 2017; 65:S58-S63.

${ }_{13}$ Magiorakos AP, Srinivasan A, Carey RB et al. Multidrug-resistant, extensively drug resistant and pandrug-resistant bacteria: an international expert proposal for interim standard definitions for acquired resistance. Clin Microbiol Infect 2012; 18:268-81.

${ }^{14}$ Az Országos Epidemiológiai Központ Tájékoztatója a Nemzeti Nosocomialis Surveillance Rendszer 2017. évi eredményeiről https://www.antsz.hu/data/cms88661/NNSR 2017.pdf (Elérve: 2018. 12. 30.)

${ }^{15}$ Abat C, Fournier P-E, Jimeno M-T et al. Extremely and pandrug-resistant bacteria extra-deaths: myth or reality? Eur J Clin Microbiol Infect Dis 2018; 37(9):1687-97.

${ }^{16}$ Dobbin C, Maley M, Harkness J et al. The impact of pan-resistant bacterial pathogens on survival after lung transplantation in cystic fibrosis: results from a single large referral centre. J Hosp Infect 2004; 56:277-82.

${ }^{17}$ Hadjiliadis D, Steele MP, Chaparro C et al. Survival of lung transplant patients with cystic fibrosis harboring panresistant bacteria other than Burkholderia cepacia, compared with patients harboring sensitive bacteria. J Heart Lung Transplant 2007; 26:834-8.

${ }^{18}$ Falagas ME, Rafailidis PI, Matthaiou DK et al. Pandrug-resistant Klebsiella pneumoniae, Pseudomonas aeruginosa and Acinetobacter baumannii infections: characteristics and outcome in a series of 28 patients. Int J Antimicrob Agents 2008; 32:450-4.

${ }^{19}$ Elemam A, Rahimian J, Mandell W. Infection with panresistant Klebsiella pneumoniae: a report of 2 cases and a brief review of the literature. Clin Infect Dis 2009; 49:271-4.

${ }^{20}$ Magyarország népessége. KSH statisztika https://www.ksh.hu/docs/hun/eurostat tablak/tabl/tps00001.html (Elérve: 2018. 12. 30.)

${ }^{21}$ de Kraker MEA, Stewardson AJ, Harbarth S. Will 10 million people die a year due to antimicrobial resistance by 2050 ? PLoS Med 2016; 29(13):e1002184. 